University at Buffalo School of Law

Digital Commons @ University at Buffalo School of Law

Journal Articles

Faculty Scholarship

2007

\title{
Narrative, Disability, and Identity
}

David M. Engel

University at Buffalo School of Law

Frank W. Munger

New York Law School

Follow this and additional works at: https://digitalcommons.law.buffalo.edu/journal_articles

Part of the Law and Society Commons

\section{Recommended Citation}

David M. Engel \& Frank W. Munger, Narrative, Disability, and Identity, 15 Narrative 85 (2007).

Available at: https://digitalcommons.law.buffalo.edu/journal_articles/467

Also available at Project MUSE.

C. ${ }_{\text {COPYRIGHT }}^{\text {N }}$

This Article is brought to you for free and open access by the Faculty Scholarship at Digital Commons @ University at Buffalo School of Law. It has been accepted for inclusion in Journal Articles by an authorized administrator of Digital Commons @ University at Buffalo School of Law. For more information, please contact lawscholar@buffalo.edu. 


\section{Narrative, Disability, and Identity}

\section{INTRODUCTION}

The articles in this cluster demonstrate that narrative has many meanings and potential uses in the study of disability rights. Like the other contributors, we are strongly committed to scholarship that draws on narrative (Engel and Munger. Rights of Inclusion). We share the sense that narrative can help to breach the barriers of detachment, doctrinal technicality, skepticism, and even irony that often separate legal scholars from the actual life experiences on which they should draw when they write about disability — or other social issues. Yet, despite our attraction to the "authenticity" of narrative, we are equally impressed with the fact that narrative is essentially a fabrication. By this we do not mean that the stories we present are necessarily untrue but that they are put together, or spun out, by the narrators in particular ways as they draw on remembered experiences, perceptions, and feelings. In our research, we had the opportunity to witness the creative process of constructing

David M. Engel is SUNY Distinguished Service Professor and Director of International Programs at the State University of New York at Buffalo School of Law. He has conducted fieldwork-based research on the role of law in the lives of ordinary people in the United States and in Southeast Asia and has studied disability rights issues involving children and their families as well as adults. Other work involves research on injuries and communities in America and Thailand. His various books and articles include Rights of Inclusion: Law and Identity in the Life Stories of Americans with Disabilities (University of Chicago 2003) (with Frank Munger). Engel is a past president of the Law \& Society Association.

Frank Munger is Professor of Law at New York Law School and Adjunct Professor at the State University of New York at Buffalo School of Law. Recent books include edited volumes Law and Poverty (Ashgate 2006) and Living Below the Line: The New Ethnography of Poverty, Low-wage Work, and Survival in the Global Economy (Russell Sage 2002). His current research interests include human rights in Southeast Asia, welfare administration, and social citizenship in the United States, as well as further work with the co-author of this article on the subject of rights. He is a former President of the Law \& Society Association and former General Editor of the Law \& Society Review. 
narratives and saw how the narrators continually revised and transformed their stories, even as our conversations with them proceeded. We concluded that it was worth trying to understand how and why these stories were told in different ways at different times by the individuals whose lives were literally at stake in the process.

In this essay, we will discuss a double process of fabrication in relation to the life-story narratives of individuals with disabilities. For it is not only the narratorsour interviewees - but also we the authors who attempt to make something of these stories. We want to explain first why our own presentation-which is also a type of fabrication-has drawn on disability narratives in this particular way.

As researchers, we are interested in why and how rights become active or fail to become active in the lives of their intended beneficiaries. Much of the scholarship on rights - including disability rights - assumes that they become active only when an individual makes a rights-based claim. Indeed, many researchers focus only on claims presented to an official legal institution (as opposed to a claim presented unofficially to, for example, an employer or the owner of a building), and a great deal of legal scholarship confines its analysis to the extremely rare cases that are litigated and appealed. Research on formal and explicit rights claims and appellate court decisions can tell us many things, but we do not think it can answer fully the question we want to ask: Why and when do rights actually make a difference in the everyday lives of the individuals for whom they were created?

In order to answer this question with particular reference to employment, we interviewed 60 men and women with disabilities-some were wheelchair users and others had learning disabilities. ${ }^{1}$ We did not select them on the basis of their activism or their heightened rights consciousness but because they represented a wide range of ordinary people. We originally intended to elicit narratives about particular employment conflicts, but we soon found that our interviewees wanted to offer "lifestory narratives"- put-together accounts of their lives beginning in early childhood and continuing through their educational experiences to their involvement, or lack of involvement, with employment. These life-story narratives became the centerpiece of our efforts to analyze the role of rights in everyday life.

In our research, we draw on the work of Bruner, Goffman, and others ${ }^{2}$ in viewing life-story narratives as the device all humans use to make sense of their experiences, to assemble the pieces of their remembered past into a story that makes sense to them and explains who they are. Life-story narratives look forward as well as backward. By constructing the identity of the narrator in particular ways, the narratives position the protagonist for new possibilities in the future, for "new living action"3 consistent with the identities they have constructed. As individuals move forward into new experiences, these are absorbed into the life-story narratives and become part of the continual process of revision and transformation.

We viewed the fluidity and dynamism of the narratives as one of the qualities we most needed to understand. For us, the essential quality of narratives was not their facticity - not the actual historical events they recounted-but their role in a process of identity creation and transformation. Focusing on this process in which life-story narratives are so central, we have proposed a "recursive theory of identity and rights" (78-105). Life-story narratives first suggested to us that identity holds a 
key to understanding how rights, such as those in the ADA, become active in the lives of intended beneficiaries. Perceptions of who one is and where one belongs in relation to others play a critical role in determining whether rights are understood as relevant. Individuals who tended to perceive their own identities in terms of disabling consequences rather than personal capabilities often failed to view rights as relevant to their life experiences, because they assumed that employment barriers resulted from their own limitations rather than from a failure by others to provide proper accommodations. Conversely, individuals who tended to perceive their identities in terms of an essentially capable Self who also had a disability were more likely to view employment barriers as a denial of rights and as an inappropriate exclusion from the opportunity to engage in productive employment.

We observed that rights very often affect the identities of their intended beneficiaries even when no rights claim is asserted and, in some cases, even when the individual is unaware of rights. Disability rights typically operate in this way by changing institutional practices, physical environments, cultural perceptions, and self-understandings. In the narratives of our interviewees, we witnessed all of these identity-transforming effects, and they, in turn, affected perceptions of rights, even by persons who never made a formal rights claim.

In putting together our story of rights, we found it important to understand why these subtle and indirect effects of rights were more pronounced for some individuals than for others. Our attempt to answer this question led us to contrast the narratives of individuals who were similarly situated in many respects yet differently situated in ways that we thought might be significant. By making paired comparisons of life-story narratives, we could control for most qualities and then explore the effects of variation in one or two key qualities, such as gender or age. When considering the narratives of women, for example, we could compare them directly to similarly situated men; and we could do the same for older and younger interviewees, for those in the working class and middle class, for Blacks and Caucasians, and so on. Such comparisons enabled us to see more clearly how particular social and personal factors affected the role of rights, but they also reminded us - in a way that single-person narratives could not-of the rich variability of human experience.

We would like to illustrate our approach to the use of narrative by presenting a particularly interesting paired comparison. In the discussion that follows, we focus on gender as we consider Andrea Plachetzki and Al Tasker, two middle-aged interviewees who both experienced serious physical disabilities after their careers were already well underway.

\section{ANDREA PLACHETZKI AND AL TASKER ${ }^{4}$ : GENDER AND RIGHTS}

The life-story narratives of Andrea Plachetzki and Al Tasker are strikingly similar in many respects. They were both in their early 50s at the time of our interview. Both were born into Catholic families in Western New York and worked from an early age: Andrea at her father's fruit and vegetable store and $\mathrm{Al}$ as a teenage sports 
columnist for a local newspaper. Both experienced serious, physically disabling illnesses in mid-career, which affected their mobility and their manual dexterity: Andrea had rheumatoid arthritis and $\mathrm{Al}$ had multiple sclerosis. Both used wheelchairs at the time of our interviews. Yet Andrea and Al differed in one obvious and important way-their gender. A comparison of their life-story narratives therefore offers a unique insight into some of the ways in which gender can affect how rights become active in the lives of their intended beneficiaries.

\section{Andrea Plachetzki}

As a shopkeeper's daughter working in the family grocery, Andrea learned at an early age about diligence, hard work, and the importance of serving others. Her father was often absent, so it is her mother and especially her grandfather who shaped this early experience. In Andrea's words, her grandfather "taught me the importance of other people interacting with you, he taught us kindness, he taught us hope, hope for the future." Her grandfather was the first of three male mentors who greatly influenced the development of Andrea's identity.

Andrea Plachetzki was the first in her family to attend college. After graduation, her early lessons in life skills were reinforced by a long employment relationship as office assistant to an old-fashioned doctor with a solo practice, who is the second of the older male mentors in her narrative. As Andrea recalls, "I liked him, I liked the place, and it was the greatest thing that happened to me, it was really great.... It was a one-man operation. It was simple." Yet after working with the doctor for ten years, she suffered the first attack of rheumatoid arthritis, beginning with a tingling in her toes and, within two weeks, ending with total confinement to her bed for an entire summer. Almost miraculously, after treatment with "massive doses of cortisone and aspirin," Andrea's symptoms completely disappeared for twelve years. Yet within weeks of her return to work, her doctor-employer died of cancer.

After a series of temporary jobs in the medical field, Andrea eventually accepted employment as a clerk at AM\&A's, a large Buffalo department store. Here she worked again as a Girl Friday to a vice-president whom she came to admire as "the epitome of the executive." Later in life, Andrea would remember Mr. Lawrence's approach to conflict situations, which appeared to have influenced her own style as a disability activist: "He could kill people, he could kill people with kindness you wouldn't believe. He could fire you, and you'd say, 'Oh, thank you.' Oh yeah, I'm serious." Andrea emphasizes another important aspect of her employment at AM\&A's by describing it as "a family-type thing." Her attraction to maintaining family-like relationships in the workplace may have been particularly significant for Andrea, who remained single and had no nuclear family of her ownno spouse, children, or grandchildren.

When her rheumatoid arthritis returned after ten years of employment at AM\&A's, it attacked her hip, knees, and hands. Soon she was unable to use the typewriter or adding machine. Although her disability predated the passage of the ADA, she felt that "they accommodated me as much as they could possibly do" by in- 
stalling a bar in the bathroom and widening a door. Nevertheless, she and Mr. Lawrence eventually arrived at what she terms a "mutual decision" that she should resign.

Upon retirement from AM\&A's, Andrea experienced further physical difficulties. After knee replacement surgery, she was dropped by two nurses and broke both of her legs, requiring casts "from my toes up to my hips." Everybody told her to sue the care providers, but she disagreed, observing that her bones were very brittle. After that point, she used a wheelchair fulltime. A few months before the interview, she had hand surgery. Then, while Andrea was riding in a wheelchair van, an obese fellow passenger fell across her and injured her legs, requiring further surgery. The accident occurred, according to her narrative, because the driver of the van was speeding, yet she does not characterize his behavior in terms of a legal violation nor did she consider legal action against him or the van company.

In recounting her life story, Andrea never interprets her setbacks as infringements of her rights. It may seem paradoxical, then, that she characterizes herself as a disability activist and a "fighter." She was the president of a Fellowship of the Disabled, and she constantly meets with and counsels other persons with disabilities. Furthermore, she successfully challenged decisions to deny her food stamps and reimbursement for new shoes, and she obtained Senator Moynihan's help in getting rental assistance money. Yet, when she concluded that K-Mart violated their legal obligation to install automatic door openers, she did not interpret their conduct as a deprivation of her rights. She simply waited outside the store until someone opened the door for her. In her mind, it is completely acceptable to make the bureaucracy observe the correct forms and procedures, but it never even occurs to her to launch an independent claim that her civil rights have been violated under state or federal law.

Similarly, she does not consider numerous unsuccessful job applications following her recent paralegal training as possible rights violations. Instead, she observes that she was "overqualified" because of her extensive work experience, and she believes that prospective employers considered her too old. She admits that those who conducted the employment interviews were very careful in their statements concerning her disability - "they had to change their script quite a bit." Yet where others might perceive employment discrimination based on age or disability, Andrea feels she was treated fairly: "Oh, I had no problem there, no."

\section{Al Tasker}

Al Tasker's life-story narrative parallels Andrea Plachetzki's in many respects, but it differs in ways that are related to their gender differences. Al tells a story of individual striving and achievement. The women we interviewed who were of Andrea's generation frequently had employment experiences like hers, working as a valued assistant or office manager for a senior male boss. Al's career was quite different. Although he, too, had bosses in his various jobs, he never perceived them as grandfatherly mentors nor as comparable to family members. Although he, too, had 
friends in the workplace, he does not characterize relationships with friends or colleagues by using the warm, familial terms that are so conspicuous in Andrea's narrative.

Al's career as a sportswriter began in the eighth grade, when he wrote a column for the newspaper in the small town where he grew up. He cut short his college career to take a full time job with yet another newspaper and then moved rapidly from one newspaper job to another, eventually working twelve years for a major city newspaper until the time of his retirement in 1980. While employed as a sportswriter, he also founded a statewide sportswriters association and served as its president, and he established an independent service to evaluate high school athletes for college recruitment. Al had been diagnosed with multiple sclerosis in the mid-1960s, early in his career, but the symptoms were mild at first. By the time of his retirement fifteen years later, he was unable to walk and was legally blind.

Al's narrative is rich with stories of the jobs he has held, the assignments he pursued, the famous sports figures he met, and the organizations and events he helped to set in motion. Unlike Andrea, however, he seldom mentions a network of personal relationships that supported and sustained him during difficult times. He does acknowledge friends who "kind of helped me out." He adds, "I'd always maintained a strong rapport with my fellow journalists." Yet his description of friendships is spare and emotionally tepid in comparison with Andrea's glowing tribute to her friends and relatives. One feels that his large network of friends and social relationships reflect his gregarious temperament but that few of these connections are deep and enduring.

While Andrea Plachetzki remained single all her life, Al Tasker most definitely did not. When we interviewed him, he was happily married to his fifth wife. Al's serial marriages, several of which involved self-conscious efforts to find women who would take care of him at particular points in his life, contrast dramatically with Andrea's assiduous construction of relational networks that she describes in familial terms. His current marriage is the result of a want-ad he placed in the newspaper at a time when he needed both companionship and personal assistance. Al has sought, and for the most part found, marital support that enabled him to pursue his solo career as a recognized expert on high school sports in the Western New York region.

Al's career achievements are foremost in his narrative, and his account of his progressive physical deterioration focuses mainly on the performance of his job. As Al's illness imposed additional restrictions on his physical abilities, he had to consider how and whether he could continue to work for the newspaper. He observes that the newspaper never provided any help, except to give him an electric typewriter when he needed it. At the same time, he admits that he never asked for any accommodations: "I tried real hard not to let my disability ever, see, I wouldn't want that to influence their thinking." Even so, he feels that his disability affected the newspaper's view of him as an employee: "I wasn't encouraged, or sometimes even, probably on assignments, I was probably discouraged...." For example, the newspaper hired a less experienced colleague instead of promoting $\mathrm{Al}$ to a position he desired. And although the newspaper gave the newly hired reporter a fax machine to submit stories from home, $\mathrm{Al}$ was never offered a similar arrangement. Nevertheless, before 
our interview, it had never occurred to $\mathrm{Al}$ that he had been the victim of disability-related employment discrimination (although such discrimination would not have been illegal at that time).

By 1980, Al was using a wheelchair, his vision had deteriorated, he was unable to drive, and the newspaper was "kind of ushering me out of the whole thing." $\mathrm{He}$ then observed that the ADA would no longer permit such behavior: "You couldn't do that today. Americans with Disabilities Act, all sorts of other stuff that's cropped up since then. But in 1980, 'Hey, go away, kid,' you know."

Al Tasker's knowledge of the ins and outs of government benefits law resembles Andrea Plachetzki's, and, like her, he has fought successfully for benefits and entitlements. Like her he has a general knowledge of the ADA but no specific sense of the rights it may have conferred. In his case, the employment provisions of the ADA may be less relevant, since he, unlike Andrea, did not actively seek a job postADA. Nevertheless, a more rights-conscious person in his situation might have imagined accommodations under the ADA that could have enabled him to resume a newspaper job despite his disability. Yet, like Andrea, he has never contemplated disability rights litigation. A leading disability rights attorney who had helped to preserve Al's Social Security Disability payments after his retirement urged him to bring a "high profile" lawsuit against the government for the lifestyle restrictions imposed on recipients of in-home support services who wish to leave the house to attend sporting events or participate in other activities. Although he recognized that such a lawsuit might benefit others as well as himself, $\mathrm{Al}$ resisted participating in this sort of legal action. He explained that he did not yet feel ready for "super-high visibility," describing himself as a "self-made agoraphobe." Nevertheless, the offer by a respected attorney to bring a lawsuit on Al's behalf reinforced Al's sense that he was entitled to the unfettered, independent pursuit of his own interests and that his rights were violated by government restrictions.

\section{CONCLUSION}

In this article, we have presented and compared the life-story narratives of two individuals-Andrea Plachetzki and Al Tasker-whose backgrounds, disabilities, and engagements with the law were similar in many respects. Because of their many similarities, and because neither Andrea nor $\mathrm{Al}$ ever invoked disability rights in official or unofficial settings, one might be tempted to conclude that rights played no significant role for either of them. We think it would be a mistake to draw such a conclusion.

Our reliance on life-story narratives has led us to a recursive theory of identity and rights, by which we mean that rights are viewed as relevant only to the extent that one's identity-consisting of a complex mix of self-perceptions and the perceptions of others - makes rights seem relevant; but at the same time, rights can transform identities and create new perceptions of ability and opportunity that may make people either more or less inclined to embrace rights in their thoughts and actions. A recursive theory of rights emerges from the longer view that life-story narratives 
provide. Over a longer span of time, one can observe identities develop and change, and one can observe the effects of rights taking hold.

Further, a recursive theory of rights emphasizes the often subtle and indirect yet extremely important effects of rights for ordinary people. Although most discussions of legislation and case law have focused on the more formal manifestations of rights, we contend that it is equally important for policymakers to acknowledge the less formal manifestations that we have described here, which were far more significant for all of our interviewees than the direct effects of official law or legal institutions.

By focusing on these subtle and indirect effects of rights, we can point to some key differences in the narratives of Andrea Plachetzki and Al Tasker. We suggest that these differences between two individuals who were similar in so many ways are rooted in one of the few ways in which they were markedly dissimilar-their gender. The identities that emerge from Andrea's and Al's narratives differ in large part because of their gendered experiences from childhood through their careers and their mid-life experience with physical disability. Al's defiant individualism is the product of a solo career that he portrays as the result of his own efforts and initiative. Throughout his career, he relied on the support of his wives, particularly as his physical limitations became more pronounced, but even his marriages are described in terms of his own practical and efficient arrangements. By contrast, Andrea Plachetzki never considered an instrumental use of marriage to further her career. Indeed, she never shared Al's assumption that a solo career was possible, and she always viewed her work in terms of the close, family-like relationships that she found in the workplace-often under the mentorship of a grandfatherly male authority figure.

The divergent identities that emerged over time were shaped by the different professional and social opportunities available to males and females as they entered adulthood in the early 1960s and sought employment. These identities, in turn, affected the ways in which Andrea and Al coped with quite similar disabilities in midcareer, and they affected as well the perceived relevance of law. Despite her willingness to take on the welfare bureaucracy, Andrea ignored any possibility of an individual legal claim against non-governmental defendants-against the nurses or the van driver who injured her or against the prospective employers who may have discriminated against her in violation of the ADA. Indeed, she seemed oblivious to the possibility that such a claim might be brought. Al shared Andrea's willingness to challenge the government bureaucrats, but also seemed gratified and even energized by his lawyer's suggestion of the possibility of "high profile" litigation-a suggestion he nevertheless rejected. His view of the law was more consistent with the egoistic individualism that sustained him throughout his career. In a subtle but very important way, rights became active in Al's life by reinforcing his identity and confirming his sense of entitlement to a successful solo career. For Andrea, rights never became active in this way.

We think it important to recognize that differences in identity-such as the gender differences we have explored in this paper-may make rights less effective for some individuals than for others. Although we cannot generalize from these two life 
stories to the role of rights for all men and women, we do discern some potentially important gendered differences in the ways in which rights affected, and failed to affect, $\mathrm{Al}$ and Andrea as well as the many other men and women we interviewed. It may be valuable for policymakers to recognize how differently rights can intersect the life stories of men versus women, but this recognition will be possible only if we expand our focus beyond formal rights claims to the indirect and constitutive role of rights in the everyday lives of ordinary people. Gender is not unique in this respect. Similar differences in identity and rights consciousness are associated with race, social class, religion, age, and the nature and timing of the disability itself (see Engel \& Munger Chapter Five).

We note that the careers of both Andrea and Al began in the pre-ADA era, and their perceptions of both gender and rights are likely to have been strongly influenced by this temporal factor. We have some evidence from interviews with younger men and women that a generational shift is occurring, although the picture is complex. Such social and cultural shifts have great significance for constituting the identities of persons for whom disability rights are intended. To some extent, these shifts occur independently of the law, but we would again insist on a recursive perspective. That is, we think the role of law not only is affected by but also produces some of these cultural and social changes.

Finally, our interviews with Andrea and Al, as well as interviews with many others, suggest that policymakers may succeed by considering the law's interplay with identity. Because the law influences the social and cultural environment in which identities are formed, and because all of our interviewees were notably reluctant to assert their rights openly and explicitly, it may be appropriate for policymakers in the future to place greater emphasis on environmental and institutional changes rather than relying primarily on individual rights claims. Because the formation of identity begins at an early age and is fundamental to subsequent experience, interventions early in the life course that positively influence the identity of persons with disabilities are particularly powerful. Neither Andrea nor Al would have benefited directly from such interventions, since their disabilities occurred relatively late in life, but the careers of many others who had childhood disabilities might have flourished. Life-story narratives provide a deeper understanding of the ways in which rights become active or fail to become active, and we hope that some of these insights may direct policy concerns away from a predominant reliance on the rare claims of individual litigants and toward the far more common yet subtle and complex patterns in which rights affect—or fail to affect—-the opportunities for inclusion of people like Andrea and Al.

\section{ENDNOTES}

1. The research we undertook to explore narrative, identity, and the effects of the Americans With Disabilities Act was supported by the Law and Social Sciences Program of the National Science Foundation (Grant No. SES-9411919). Our research is described in much greater detail in our book. 
2. We have found the work of clinical psychologists George Rosenwald and Richard Ochberg particularly useful. They describe therapeutic encounters with patients in which the two-way relationship between narrative construction and action plays a central role. The evolving interplay between interactions with others and construction of a narrative of identity lies at the core of our theory of the "recursive relationship between rights and identity" that we describe below.

3. The phrase is Rosenwald's (272-3).

4. The names we use here are pseudonyms.

5. In presenting these two narratives, we follow the convention of using the "ethnographic present" to describe what Andrea and Al said to us. Readers should note, however, that both interviews took place in the early 1990s.

\section{WORKS CITED ${ }^{1}$}

Bruner, Jerome. Acts of Meaning. Cambridge, MA: Harvard Univ. Press, 1990.

Engel, David M. and Frank W. Munger. Rights of Inclusion: Law and Identity in the Life Stories of Americans with Disabilities. Chicago: Univ. of Chicago Press, 2003.

Goffman, Erving. Stigma: Notes on the Management of Spoiled Identity. New York: Simon and Schuster, 1963.

Rosenwald, George C. "Conclusion: Reflections on Narrative Self-Understanding." In Storied Lives: The Cultural Politics of Self-Understanding, edited by George C. Rosenwald and Richard L. Ochberg, 265-89. New Haven, CT: Yale Univ. Press, 1992.

Rosenwald, George C. and Richard L. Ochberg, eds. Storied Lives: The Cultural Politics of SelfUnderstanding. New Haven, CT: Yale Univ. Press, 1992. 